Eur. J. Clin. Chem. Clin. Biochem.

Vol. 29, 1991, pp. 405-410

(C) 1991 Walter de Gruyter \& Co. Berlin. New York

\title{
Highly Sensitive Immuno-Assays for the Determination of Cotinine in Serum and Saliva \\ Comparison Between RIA and an Avidin-Biotin ELISA ${ }^{1}$ )
}

By S. Benkirane ${ }^{1}$, A. Nicolas ${ }^{2}$, Marie-Madeleine Galteau ${ }^{1}$ and G. Siest ${ }^{1}$

1 Laboratoire du Centre de Médecine Préventive et Centre du Médicament (URA CNRS 597), Vandoeuvre-lèsNancy, France

2 Laboratoire de Chimie Analytique, URA CNRS 597, Faculté des Sciences Pharmaceutiques et Biologiques, Nancy, France

(Received December 4, 1990/March 22, 1991)

Summary: Two immuno-assay methods (RIA and ELISA) have been developed for the accurate and sensitive measurement of cotinine in human body fluids (serum, saliva).

RIA uses $\left[{ }^{3} \mathrm{H}\right]$ cotinine as antigen and charcoal/dextran for separating cotinine-bound antibodies from the free derivative.

Another technique (ELISA) was developed to avoid the use of radio-labelled compounds and to determine cotinine in large populations, including passive or non-smokers who usually present very low concentrations.

The two techniques were analytically validated. The detection limit was similar $(0.1 \mu \mathrm{g} / \mathrm{l})$ and the precision was better than $10 \%$ for both techniques.

Non-smoker values ranged from 0.1 to $17 \mu \mathrm{g} / \mathrm{l}$ by ELISA and 0.1 to $27.5 \mu \mathrm{g} / \mathrm{l}$ by RIA, whereas smoker values ranged from 50 to $1000 \mu \mathrm{g} / \mathrm{l}$ (ELISA) and from 70 to $800 \mu \mathrm{g} / \mathrm{l}$ (RIA).

The comparative analysis of cotinine in 96 human sera revealed a good correlation between the two methods $(r=0.97)$ and a reliable discrimination between the populations of non-smokers and smokers. As usual, the ELISA is more rapid ( $4 \mathrm{~h} 30 \mathrm{~min}$ ) than the RIA (longer than $48 \mathrm{~h}$ ). ELISA is proposed for use in the epidemiological investigation of the human tobacco risk.

\section{Introduction}

Cotinine is the major metabolite of nicotine. In humans, $70 \%$ of nicotine is metabolized (oxidized) to cotinine, $4 \%$ is oxidized differently, $9 \%$ is excreted unchanged in urine and the metabolic fate of the remaining $17 \%$ is still unknown (1).

') This work was partly supported by "Ld Caisse Nationale d'Assurances Maladies des Travailleurs Salariés" and by INSERM CRE 888010. Saâd Benkirane benefited from a student grant from "La Société de Tabacologie".
Cotinine elimination in different body fluids varies significantly (2). In adult non-smokers, the serum concentration of cotinine is $1.5 \mu \mathrm{g} / \mathrm{l}$, and concentrations in saliva and urine are 1.7 and $5.0 \mu \mathrm{g} / \mathrm{l}$, respectively. In smokers, these values increase about 180 fold in plasma and in saliva, and 280 fold in urine (3). Serum cotinine is considered to be a useful biological indicator of environmental-tobacco-smoke exposure (4). A significant difference in cotinine levels between races has been reported. In white and black children unexposed to tobacco smoke, the serum co- 
tinine level is $0.20 \pm 0.44 \mu \mathrm{g} / \mathrm{l}$ and $1.87 \pm 2.38 \mu \mathrm{g} / \mathrm{l}$, respectively. This difference was greater when children were exposed to tobacco (4).

The technique of Langone et al. (6), as modified by Castro et al. (5) uses tritium-labelled cotinine, and charcoal adsorption for separating the cotinine-bound antibodies from the free derivative. No improvement of the detection limit of this test in serum has been reported. Recently, Greenberg et al. (7) achieved a detection limit of $0.37 \mu \mathrm{g} / \mathrm{l}$ using ${ }^{125} \mathrm{I}$-labelled cotinine.

The aim of this work was to develop a sensitive radioimmuno-assay (RIA) and a one-site enzymometric assay (ELISA) for the quantification of cotinine. The most convenient of these methods for routine work will be used for epidemiological studies, which require reliable discrimination between active smokers, passive smokers and non-smokers.

\section{Materials and Methods}

\section{Reagents}

All reagents were of analytical grade. Trans-4'-carboxycotinine and sheep cotinine antiserum prepared using trans-4'-carboxycotinine conjugated to keyhole limpet haemocyanin as immunogen (cross-reaction at $50 \%$ displacement was $100 \%$ for cotinine and less than $1 \%$ for nicotine) were obtained from International Laboratory Services (London, GB). ${ }^{3} \mathrm{H}$-labelled cotinine (specific activity $57.8 \mathrm{TBq} / \mathrm{mol}$ ) was obtained from Amersham (Aylesburg, GB). Charcoal-dextran was from C. E. A. (Gif/Yvette, F), Gelatin-Bacto from Difco (Detroit, Mi, USA), Casein vitamin-free from Serva (Heidelberg, D), and Protein A sepharose from Pharmacia (Uppsala, S). Biotin amidocaproate- $\mathrm{N}$-hydroxysuccinimide ester, extravidin peroxidase conjugate, $o$-phenylenediamine dihydrochloride, hydrogen peroxide $30 \%(300 \mathrm{~g} / \mathrm{kg})$, polylysine, $(-)$ cotinine, and 1-ethyl-3(3-dimethylaminopropyl) carbodiimide were from Sigma (St. Louis, Mo, USA). All other chemicals were from Merck (Darmstadt, D). Scintran, cocktail EX was purchased from BDH chemicals Ltd (Poole, GB). EIA 96 wells microtitre plates with high binding capacity were from Costar (Cambridge, $\mathrm{Ma}$, USA).

\section{Human specimens}

Blood from 96 supposed healthy subjects attending the Centre for Preventive Medicine (Vandœuvre-Nancy, F) for health screening was collected in tubes containing clot activator (from Becton Dickinson, Mountain View, Ca, USA) and centrifuged at $1200 \mathrm{~g}$ for 10 minutes. Serum was then frozen at $-20^{\circ} \mathrm{C}$ until analysis.

Whole mixed saliva was collected (between 8.00 and 9.00 a.m.) from the same population using salivette systems (Sarstedt, Nümbrecht, D). After centrifugation at $1200 \mathrm{~g}$ for 10 minutes the clear saliva was analysed or frozen at $-20^{\circ} \mathrm{C}$.

\section{Radio-immuno-assay (RIA)}

The assay was performed in glass tubes $(10 \times 75 \mathrm{~mm})$. Tris buffer $(200 \mu \mathrm{l}) \mathrm{pH} 7.4$ (Tris- $\mathrm{HCl} 10 \mathrm{mmol} / \mathrm{l}$ containing 150 $\mathrm{mmol} / \mathrm{l}$ of $\mathrm{NaCl}$ and $1 \mathrm{~g}$ of gelatin per litre) was added to 100 $\mu l$ of $\left[{ }^{3} \mathrm{H}\right]$ cotinine in Tris buffer $\left(\mathrm{Ag}^{*}\right), 100 \mu$ l of standard or sample (Ag), and $100 \mu \mathrm{l}$ of antiserum in Tris buffer (Ab), then incubated overnight at $4^{\circ} \mathrm{C}$. A suspension $(500 \mu \mathrm{l})$ of charcoaldextran ( $2.2 \mathrm{~g} / \mathrm{l}$ in Tris buffer) was added with stirring, and the tubes were incubated at $4^{\circ} \mathrm{C}$ for $10 \mathrm{~min}$ for adsorption of the free antigen. After centrifugation at $3000 \mathrm{~g}$ for $15 \mathrm{~min}$ at $4^{\circ} \mathrm{C}$, $500 \mu \mathrm{l}$ of supernatant were mixed with $10 \mathrm{ml}$ of scintillation cocktail and counted in a Beckman counter (LS 1801).

The amounts of $\mathrm{Ag}$ in physiological fluids were determined using a standard curve.

\section{One site enzymometric assay (ELISA)}

\section{Preparation of specific reagents}

Anti-cotinine immunoglobulins $G$ were separated on a column of Protein A Sepharose. After overnight dialysis against 100 $\mathrm{mmol} / \mathrm{l}$ sodium bicarbonate $\mathrm{pH} 8.0$ at $4{ }^{\circ} \mathrm{C}$, IgG were concentrated using ultrafiltration $(1 \mathrm{~g} / \mathrm{l})$ and stored at $-20^{\circ} \mathrm{C}$ until use.

Biotinylation of anti-cotinine IgG was performed according to Cosiello et al. (8). Biotin conjugate was stored at $-20^{\circ} \mathrm{C}$ in glycerol (for fluorescence microscopy) containing $0.2 \mathrm{~g}$ sodium azide per litre. The final volume fraction of glycerol was 0.50 . The optimal dilution was determined for each batch.

Cotinine-polylysine conjugate $(2 \mathrm{~g} / \mathrm{l})$ was prepared according to the procedure described by Bjercke et al. (9) and aliquots were stored at $-20^{\circ} \mathrm{C}$ until use.

\section{ELISA protocol}

The procedure described by Bjercke et al. (9) was modified. Microtitre plates were coated with cotinine-polylysine conjugate by incubating at $4{ }^{\circ} \mathrm{C}$ overnight. The conjugate was diluted 1000 -fold in phosphate buffer, $3 \mathrm{mmol} / \mathrm{l}, \mathrm{pH} 6.35$, and $100 \mu \mathrm{l}$ of this solution were added to each well. After coating, the plates were washed three times with "casein buffer" $\mathrm{pH} 7.6$, containing $10 \mathrm{mmol}$ Tris- $\mathrm{HCl}, 10 \mathrm{mmol}$ sodium chloride, 10 mmol EDTA and $2 \mathrm{~g}$ casein per litre. The unoccupied sites were blocked by incubating the plates with "casein buffer" for $1 \mathrm{~h}$ at room temperature; the plates were then washed three times with the same buffer and used immediately.

The standard curve was obtained by adding $50 \mu \mathrm{l}$ of serial dilutions of cotinine made up in blank serum (pool of sera collected from 5 non-smokers diluted 1:5 in "Tris buffer" for RIA and in "casein buffer" for ELISA) and $50 \mu l$ of anticotinine conjugate (diluted $1: 100$ ) in the same buffer. The assay plate was incubated for $2 \mathrm{~h}$ at $37^{\circ} \mathrm{C}$ in a wet chamber. The maximum binding point $\left(\mathrm{B}_{0}\right)$ was determined by incubating $50 \mu \mathrm{l}$ of anti-cotinine conjugate with $50 \mu \mathrm{l}$ of "casein buffer". Control wells contained all reagents except anti-cotinine conjugate. After incubation, the samples were removed and the plate washed three times with "casein buffer".

A solution containing $0.66 \mathrm{mg} / \mathrm{l}$ of horse-radish peroxidaseconjugated extravidin $(100 \mu \mathrm{l})$ was dispensed into each well and the plate incubated for $1 \mathrm{~h}$ at room temperature.

Finally the plate was washed six times with phosphate buffered saline pH 7.2, containing $4 \mathrm{~g} \mathrm{NaH}_{2} \mathrm{PO}_{4} \cdot 2 \mathrm{H}_{2} \mathrm{O}, 27 \mathrm{~g} \mathrm{Na}_{2} \mathrm{HPO}_{4}$ - $12 \mathrm{H}_{2} \mathrm{O}, 8 \mathrm{~g} \mathrm{NaCl}$, and $0.5 \mathrm{ml}$ Tween 20 per litre. The activity of peroxidase bound to the plate was determined by adding to each well $100 \mu \mathrm{l}$ of freshly prepared substrate $\mathrm{pH} 5.5$, containing $100 \mathrm{mmol} \mathrm{Na} \mathrm{HPO}_{4} \cdot 12 \mathrm{H}_{2} \mathrm{O}, 100 \mathrm{mmol}$ sodium citrate, $3 \mathrm{~g} \mathrm{o}$ phenylenediamine dihydrochloride and $100 \mu \mathrm{l}$ hydrogen peroxide $(30 \%)$ per litre. The plate was then incubated for $20-$ $25 \mathrm{~min}$ at room temperature, the reaction was stopped by adding $50 \mu \mathrm{l}$ of $3 \mathrm{~mol} / \mathrm{l}$ hydrochloric acid, and the absorbance was read at $492 \mathrm{~nm}$ on a Titertek Multiskän, MCC/340 (Flow Laboratories limited, Rickmansworth, UK). 


\section{Results}

Optimization of the assay procedures

RIA: Determination of the appropriate dilutions for antibody $(A b)$ and labelled antigen $\left(A g^{*}\right)$

The dilution of $\mathrm{Ab}$ able to bind $50 \%$ of a known amount of $\mathrm{Ag}^{*}$ was chosen. Two dilutions of $\mathrm{Ag}^{*}$ were tested (20000 or 10000 counts $/ \mathrm{min})$. The antibody dilution curves were constructed by adding 300 $\mu \mathrm{l}$ of Tris buffer, $\mathrm{pH} 7.4$ to $100 \mu \mathrm{l}$ of $\mathrm{Ag}^{*}$ and $100 \mu \mathrm{l}$ of $\mathrm{Ab}$ dilutions $(1: 5,1: 10,1: 50,1: 100,1: 200$ and $1: 500)$ in the same buffer. All subsequent procedures were those described in the "radio-immuno-assay" section. The best dilution of $\mathrm{Ab}$ was $1: 150$, using the $\mathrm{Ag}^{*}$ dilution giving 10000 counts/min. For each new batch of $\mathrm{Ab}$ the best dilution should be evaluated.

\section{ELISA: Optimization of the test}

Various dilutions of cotinine-polylysine conjugate were tested. The best coating was obtained with $1: 1000$ dilution. The optimal dilution of the biotinylated antibodies was obtained with $1: 100$ dilution in "casein buffer". The best results were obtained with extravidin-peroxidase conjugate diluted to $1: 3000$ $(0.66 \mathrm{mg} / \mathrm{l})$ in the same buffer.

\section{Incubation conditions}

\section{$R I A$}

Various temperatures and incubation times were tested. The range of inhibition $\left(\mathrm{B} / \mathrm{B}_{0}>0.80\right)$ was obtained after $1 \mathrm{~h}$ incubation at $37^{\circ} \mathrm{C}$ or $16 \mathrm{~h}$ at $4{ }^{\circ} \mathrm{C}$ (fig. 1).

The incubation conditions were chosen as $16 \mathrm{~h}$ at $4{ }^{\circ} \mathrm{C}$. The sensitivity was highest for low concentrations of cotinine $(<5 \mu \mathrm{g} / \mathrm{l})$, the slope of the curve being steeper in this range.

\section{ELISA}

Several incubation temperatures and times were also tested to determine the optimal conditions, which were estimated from the minimal signal/noise ratio and within-run variability. The best detection limit $(0.1 \mu \mathrm{g} / \mathrm{l})$ was obtained after $2 \mathrm{~h}$ incubation at $37^{\circ} \mathrm{C}$ in a wet chamber.

\section{Optimization of the standard curves}

\section{RIA}

Figure 2 shows the standard curve obtained in buffer. It covered the range of cotinine content found in nonsmokers, passive smokers and active smokers (3). It

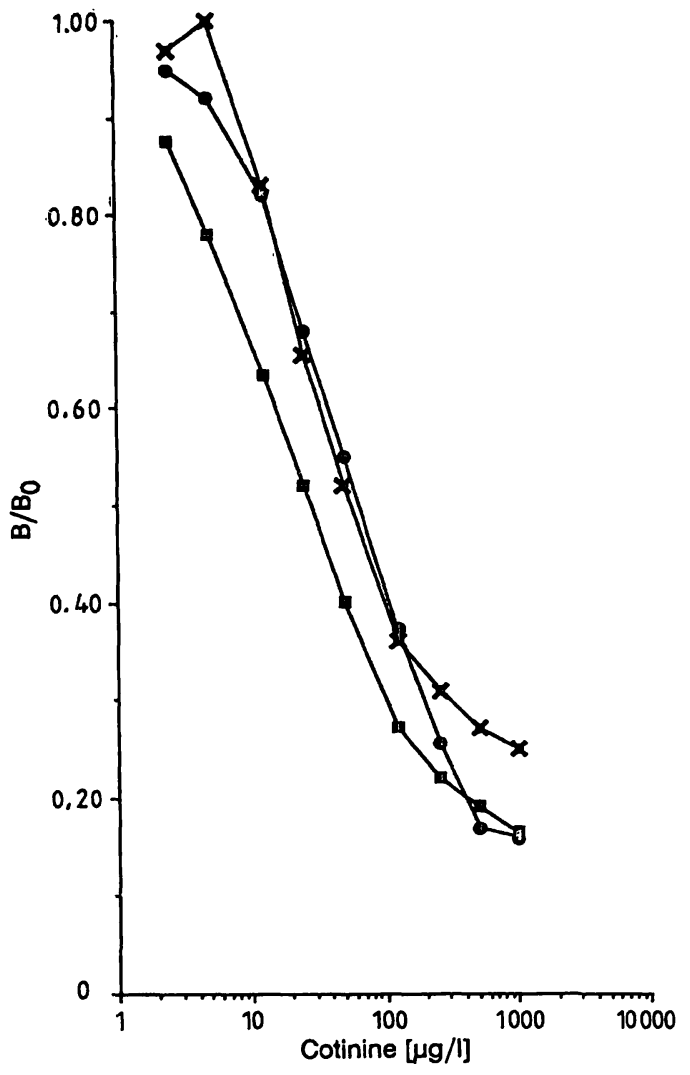

Fig. 1. RIA: Standard curves in buffer under various incubation conditions:

o-0 $1 \mathrm{~h}$ at $37^{\circ} \mathrm{C} ; \mathrm{x}-\mathrm{x} 3 \mathrm{~h}$ at $37^{\circ} \mathrm{C} ; \mathbf{\square - \square} 16 \mathrm{~h}$ at $4^{\circ} \mathrm{C}$.

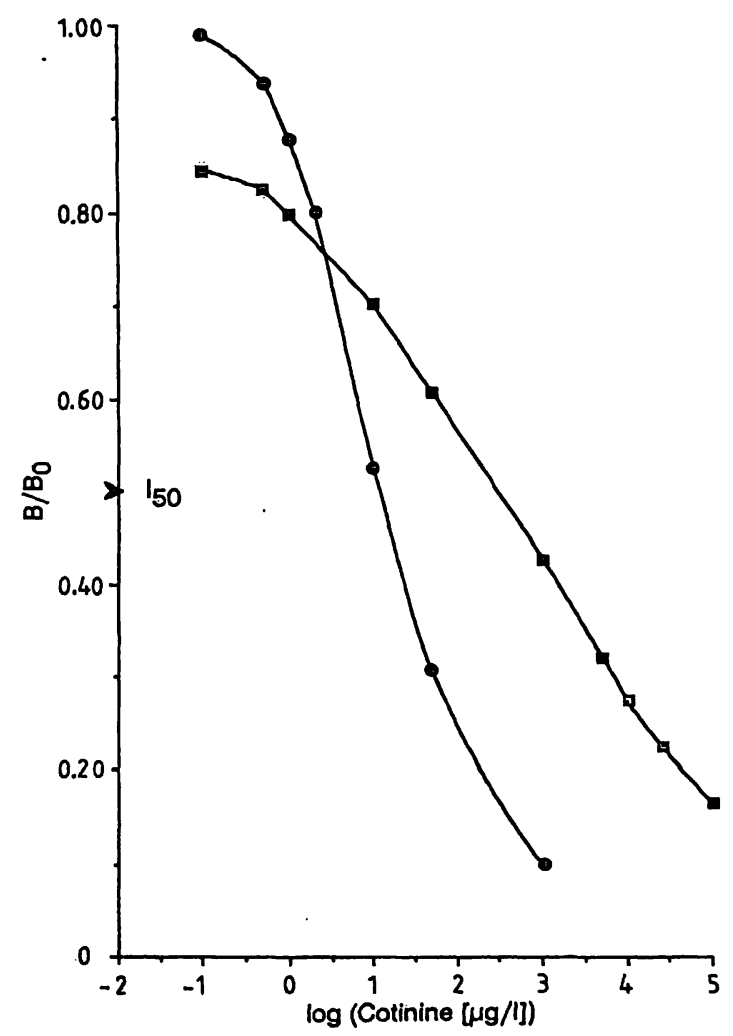

Fig. 2. RIA and ELISA standard curves for cotinine under optimized incubation conditions: - RIA (16 h at $4^{\circ} \mathrm{C}$ in buffer) - ELISA ( $\mathrm{h}$ at $37^{\circ} \mathrm{C}$ in blank serum) 
was very reproducible, showing day to day coefficients of variation of $2.9 \%$ for $50 \mu \mathrm{g} / \mathrm{l}$ and $3.7 \%$ for 500 $\mu \mathrm{g} / \mathrm{l}(\mathrm{n}=10)$. The detection limit of the test was 0.1 $\mu \mathrm{g} / \mathrm{l}$.

Standard curves made up in physiological fluids, i.e. serum and saliva, gave a similar slope and dynamic range.

\section{ELISA}

Figure 2 shows the standard curve of cotinine made in blank serum. This standard curve was reproducible when measured on 10 different days, the coefficients of variation being $5.5 \%$ for $50 \mu \mathrm{g} / \mathrm{l}$ and $7.7 \%$ for 500 $\mu \mathrm{g} / \mathrm{l}$. The detection limit was similar to that of the RIA.

\section{Precision}

The repeatability of the methods was assayed by measuring the serum cotinine level 30 times consecutively in à unique series, while the reproducibility was determined on 10 different days. The within-run and day to day coefficients of variation were less than $8.5 \%$ for RIA and less than $6 \%$ for ELISA (range $200-500 \mu \mathrm{g} / \mathrm{l})$. These variation coefficients were greater for the low values found in non-smokers: $50 \%$ for $0.1 \mu \mathrm{g} / 1$ (RIA) and less than $20 \%$ for $20 \mu \mathrm{g} / 1$ (ELISA).

\section{Linearity}

Sera of smokers were tested (fig. 3). Assays were performed by RIA and ELISA, with and without dilutions $(1: 2,1: 4,1: 10,1: 50)$ in blank serum. Good linearity was observed for ELISA. However, RIA was non-linear for concentrations higher than $400 \mu \mathrm{g} / \mathrm{l}$. In order to correlate the results obtained by both methods the samples to be analysed were diluted $(1: 2)$ in blank serum.

\section{Recovery}

Sera were spiked with cotinine and quantitated in order to calculate the analytical recovery. The mean analytical recovery tested for concentrations between 50 and $500 \mu \mathrm{g} / 1$ was $98 \%$ (range $96-104$ ) for RIA and $105 \%$ (range 103-107) for ELISA, which was acceptable for both methods.

\section{Stability in serum}

A single freezing-thawing cycle $\left(-20^{\circ} \mathrm{C} / \mathrm{room}\right.$ temperature, performed over $48 \mathrm{~h}$ ) did not give any variation in serum cotinine level. Additional cycles produced decreases of serum cotinine $(-10$ to $-33 \%)$ and must be avoided.

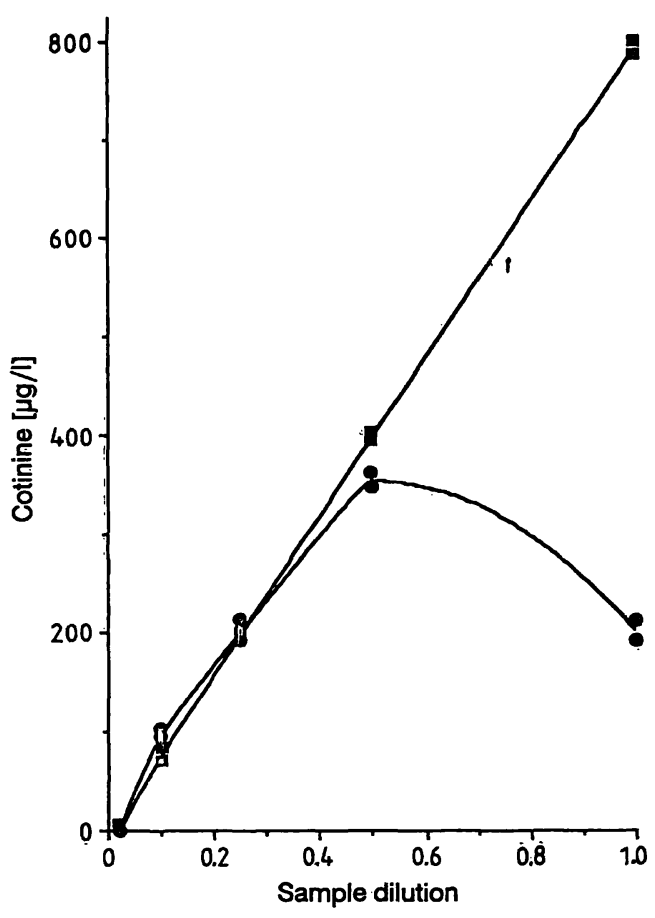

Fig. 3. Linearity ranges for RIA (e-e) and ELISA ( $(-\square)$.

Sample assays (sera)

Figure 4 shows a correlation curve for serum cotinine from 52 smokers and 44 non-smokers measured by ELISA and RIA. Good agreement was found between RIA and ELISA (RIA $\fallingdotseq 0.8736$ ELISA + 3.4495; $r=0.97 ; n=96)$.

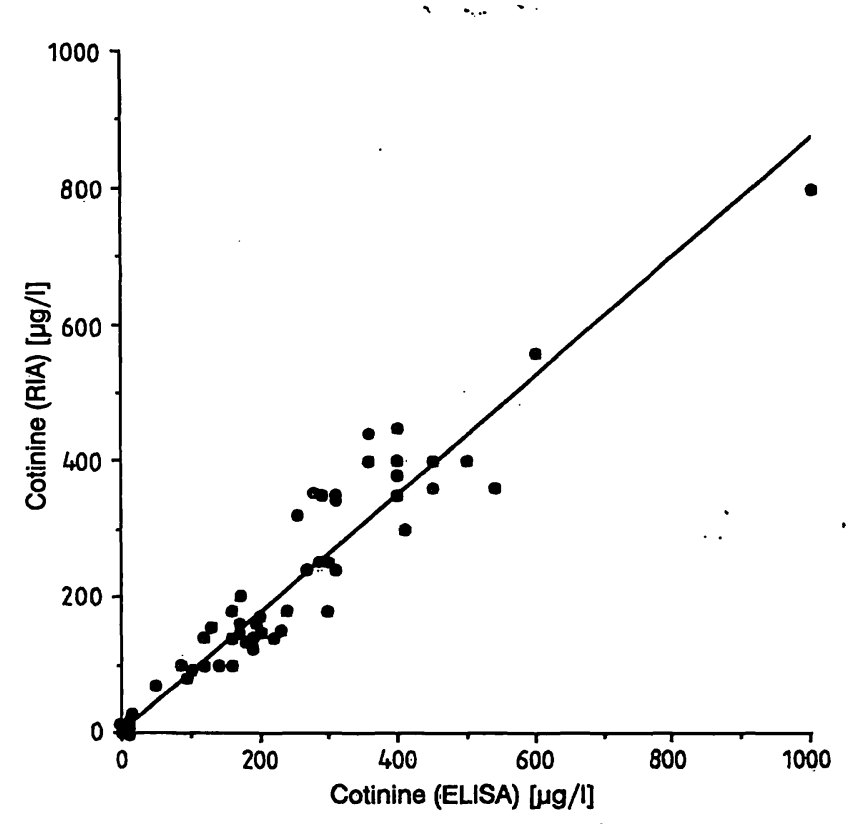

Fig. 4. Correlation between RIA and ELISA procedures. Standard inhibition curves were determined in blank serum diluted $(1: 5)$, in "casein buffer" for ELISA and gelatin buffer for RIA. The samples tested were diluted in the blank serum $(1: 2,1: 4)$ and the mean results were used. $\mathbf{n}=96$. 
The usual values for smokers and non-smokers are indicated in table 1.

Tab. 1. Serum cotinine levels obtained for active smokers and non-smokers using RIA and ELISA

\begin{tabular}{|c|c|c|}
\hline & $\begin{array}{l}\text { Active smokers } \\
\mathrm{n}=52\end{array}$ & $\begin{array}{l}\text { Non-smokers } \\
\mathrm{n}=44\end{array}$ \\
\hline \multicolumn{3}{|l|}{ RIA } \\
\hline $\begin{array}{l}\bar{x} \pm s(\mu \mathrm{g} / \mathrm{l}) \\
\text { range }(\mu \mathrm{g} / \mathrm{l})\end{array}$ & $\begin{array}{c}249.2 \pm 144.0 \\
70 \pm 800\end{array}$ & $\begin{array}{l}2.58 \pm 5.42 \\
0.1-27.5\end{array}$ \\
\hline \multicolumn{3}{|l|}{ ELISA } \\
\hline $\begin{array}{l}\bar{x} \pm s(\mu \mathrm{g} / \mathrm{l}) \\
\text { range }(\mu \mathrm{g} / \mathrm{l})\end{array}$ & $\begin{array}{c}278.2 \pm 159.6 \\
50 \simeq 1000\end{array}$ & $\begin{array}{l}2.74 \pm 4.19 \\
0.1=17.0\end{array}$ \\
\hline
\end{tabular}

\section{Discussion}

In order to easily discriminate non-smokers from smokers it is necessary to increase the detection limit and the sensitivity of cotinine measurements, and many modifications have been attempted.

Radio-immuno-assays for the measurement of cotinine are classically modifications of the Langone technique (6) using $\left[{ }^{3} \mathrm{H}\right]$ cotinine and polyclonal antiserum. In these methods a second antibody was used for separating the complexes, and this step usually required 16 h. Matsukura et al. (10) and Wald et al. (11) proposed ammonium sulphate precipitation and chloroform extraction for the determination of the cotinine level in urine. Many modifications were tested and the lowest detection limit was $0.37 \mu \mathrm{g} / \mathrm{l}$ of cotinine by radio-immuno-assay and $0.2 \mu \mathrm{g} / 1$ by gas-chromatography using nitrogen-selective detection $(4,7,12-$ 14). Using ${ }^{125} \mathrm{I}$ labelling and incubating standard or plasma samples with the antiserum for $1 \mathrm{~h}$ or for $24 \mathrm{~h}$ (non-equilibrium and equilibrium, respectively), a detection limit of $10 \mu \mathrm{g} / \mathrm{l}$ was attained. ${ }^{3} \mathrm{H}$ labelling is superior to the use of the $\left[{ }^{125} I\right]$ tyramine derivative, as it permits complete inhibition (15).

Our RIA method uses a polyclonal antiserum, $\left[{ }^{3} \mathrm{H}\right]$ cotinine and charcoal-dextran to specifically bind free antigen species in a short time (10 min).

\section{References}

1. Benowitz, N. L. (1988) Pharmacokinetics and pharmacodynamics of nicotine. In: The pharmacology of nicotine (Rand, M. S. \& Thurau, K., eds) IRL press.

2. Sepkovic, D. W. \& Haley, N. J. (1985) Biomedical applications of cotinine quantitation in smoking related research. Am. J. Public Health Briefs 75, 663-665.

3. Jarvis, M., Tunstall-Pedoe, H., Feyerabend, C., Vessey, C. \& Salloojee, Y. (1984) Biochemical markers of smoke absorption and self reported exposure to passive smoking. J. Epidemiol. Comm. Health. 38, 335-339.
The comparison (tab. 2) of this modified RIA with that previously described shows that our method gives a better detection limit $(0.1 \mu \mathrm{g} / \mathrm{l})$ than all other published techniques. Surprisingly, linearity is maintained only up to $400 \mu \mathrm{g} / \mathrm{l}$. This pseudo-hook effect is rare in competitive techniques. It may be related to partial release of adsorbed labelled antigen in the presence of high concentrations of cotinine (16). A previous dilution of the sample avoids this effect and allows reliable correlation of RIA and ELISA.

Tab. 2. Comparison of various cotinine determinations using RIA

\begin{tabular}{lllc}
\hline Labelling & Fluid & $\begin{array}{l}\text { Limit of } \\
\text { detection } \\
(\mu \mathrm{g} / \mathrm{l})\end{array}$ & Reference \\
\hline${ }^{125 \mathrm{I},}{ }^{3} \mathrm{H}$ & serum & 2 & $(6)$ \\
${ }^{125} \mathrm{I}$ & urine & 2 & $(10)$ \\
${ }^{125 \mathrm{I}}$ & serum & 10 & $(5)$ \\
${ }^{125} \mathrm{I},{ }^{3} \mathrm{H}$ & urine, saliva & 0.37 & $(7)$ \\
${ }^{125} \mathrm{I}$ & urine & 1 & $(11)$ \\
${ }^{125} \mathrm{I}$ & serum & 0.5 & $(4)$ \\
${ }^{125} \mathrm{I}$ & serum & 2 & $(13)$ \\
${ }^{125} \mathrm{I}$ & hair & 1 & $(12)$ \\
${ }^{3} \mathrm{H}$ & serum & 0.1 & this work \\
\hline
\end{tabular}

The proposed ELISA does not use commercially available reagents but it has the advantage of being more rapid than RIA. The detection limit was similar to RIA $(0.1 \mu \mathrm{g} / \mathrm{l})$. The $\mathrm{I}_{50}$ values in the respective methods were determined (fig. 2). With the RIA, $10 \mathrm{ng}$ of cotinine gave $50 \%$ inhibition, whereas $340 \mathrm{ng}$ of cotinine were required with ELISA. Using monoclonal antibodies ELISA assays are claimed to be 5-10 times more sensitive (9). The use of ELISA avoids technical precautions, expensive reagents and a long working time. ELISA is preferable for epidemiological investigation of the risks due to tobacco smoking.

\section{Acknowledgement}

We thank $Z$. Jayyosi and $S$. Ghribi for correcting the manuscript and $G$. Junger for secretarial assistance. Stabiligen SA. is acknowledged for its help.

4. Pattishall, E. N., Strope, G. L., Etzel, R. A., Helms, R. W., Haley, N. J. \& Denny, F. W. (1985) Serum cotinine as a measure of tobacco smoke exposure in children. Am. $J$. Dis. Com. 139, 1101-1104.

5. Castro, A., Monji, N., Hacer, A., Yi, J. M., Bowman, E. R. \& McKennis, H. Jr. (1980) Nicotinc Antibodies: Comparison of Ligand Specificities of Antibodies Produced against Two Nicotine Conjugates. Eur. J. Biochem. 104. $331-340$. 
6. Langone, J. J., Gjika, H. B. \& Van Vunakis, H. (1973) Nicotine and its metabolites. Radio-immuno-assay for nicotine and cotinine. Biochemistry 12, 5025-5030.

7. Greenberg, R. A., Haley, N. J., Etzel, R. A. \& Loda, F. A. (1984) Measuring the exposure of infants to tobacco smoke. Nicotine and cotinine in urine and saliva. New Eng. J. Med. 310, 1075-1078.

8. Costello, W. H., Felix, R. T. \& Giese, R. W. (1979) Enhancement of immune cellular agglutination by use of an avidin-biotin system. Clin. Chem. 25, 1575-1578.

9. Bjercke, R. J., Cook, G., Rychlik, N., Gjika, H. B., Van Vunakis, H. \& Langone, J. J. (1986) Stereospecific monoclonal antibodies to nicotine and cotinine and their use in enzyme-linked immunosorbent assays. J. Immunol. Methods $90,203-213$.

10. Matsukura, S., Sakamoto, N., Seino, Y., Tamada, T., Matsuyama, H. \& Muranaka, H. (1979) Cotinine excretion and daily cigarette smoking in habituated smokers. Clin. Pharmacol. Ther. $25,555-561$.
11. Wald, N. J., Boreham, J., Bailey, A., Ritchie, C., Haddow, J. E. \& Knight, G. (1984) Urinary cotinine as marker of breathing other people's tobacco smoke. Lancet $I, 230-$ 231.

12. Haley, N. J. \& Hoffmann, D. (1985) Analysis for nicotine and cotinine in hair to detèrmine cigarètte smoker status. Clin. Chem. 31, 1598-1600.

13. Knight, G. J., Wylie, P., Holman, M. S. \& Haddow, J. E. (1985) Improved ${ }^{125}$ I radio-immuno-assay for cotinine by selective removal of bridge antibodies. Clin. Chem. 31, $118-121$.

14. Luck, W. \& Nau, H. (1985) Nicotine and cotinine concentrations in serum and urine of infants exposed via passive smoking or milk from smoking mothers. J. Pediatrics 107, $816-820$.

15. Bjercke, R. J., Cook, G. \& Langone, J. J. (1987) Comparison of monoclonal antibodies to cotinine in nonisotopic immuno-assays. J. Immunol. Methods 96, 239-246.

16. Masseyeff, R. (1989) L'effet d'inversion à haute dose d'antigène (effet "crochet"). Immunoanal. Biol. Spec. 15, $37-38$.

Prof. Dr. Marie-Madeleine Galteau Laboratoire du Centre de Médecine Préventive 2 avenue du Doyen Jacques Parisot F-54500 Vandouvre-lès-Nancy 